Journal of Business and Tourism

Volume 05 Number 01

January - June, 2019

\title{
Earnings Management and Dividend Policy: Testing Audit Quality for the Moderating Effect
}

\author{
ASIF ZEB \\ MS Scholar, Institute of Business Studies and Leadership \\ Abdul Wali Khan University Mardan \\ asifzebkhan2020@gmail.com \\ DR. ARIF HUSSAIN \\ Assistant Professor, Institute of Business Studies and Leadership \\ Abdul Wali Khan University Mardan \\ arifhussain@awkum.edu.pk \\ DR. ALAM RAHMAN \\ Assistant Professor, National University of Modern Languages, Islamabad. \\ amrehman@numl.edu.pk
}

\begin{abstract}
The study is about the moderating effect of audit quality on the relationship between earning management and dividend policy in manufacturing sector of Pakistan. Firms listed in Pakistan Stock Exchange (PSE) have been considered to investigate the effect of earnings management on dividend policy from 2010 to 2016 in Pakistan. The dividend policy is calculated by dividend payout ratio whereas the discretionary accruals have been used for the measurement of earning management and this is taken as a proxy to estimate the earning management. The modified cross sectional model is adopted to quantity discretionary accruals. From the analysis, it is concluded that earning management has influence on dividend policy which rejects null hypothesis of the study. The regression coefficients explain that the connection is too weak that it is most near to no connection. The reason of this no connection or influence is financial decline time period, as earning management varies annually.
\end{abstract}

Key words: Earning Management, dividend policy, Pakistan Stock Exchange.

\section{Introduction}

Company managers take many important financial decisions for the company. These financial decisions play a crucial role in the achievement of company goals and objectives. In such choices dividends, an outgoing strategy is also one of the most significant choices and is important for the financial strength of the corporation (Baker and Powell, 1999). Miller and Modigliani (1961) assume that the market is perfectly efficient, and proved that changes in dividend policy carring no effect on the value of the of the firm. However as perfect efficient market does not exist, many authors provide sort of theories like the bird-in-hand theory, signaling theory, and agency theory that displays the cost of equity is increased by the payment of dividend. And the dividend paying companies attract investors more than those firms which are not making payment 
of dividends (Shah et al. 2010). Earning management is handling or in other words management of a corporation's economic revenue. Earnings play a vital element that will attract the interested parties to the firms. According to Haider et al. (2012) it should be managed and controlled by a company management. The calculation of EM ( earning management) is challenging because of changes in the accounting values. It can be premeditated by discretionary accrual which are used as substitute for earnings management in this study.

Here are diverse aspects that might be termed as elements of dividend policy such as the size of company, capitalization of market and cash balance. Pakistan is an emerging economy and is not prosperous with high development. Usually, large corporations are controlled and possessed by families so the conflict takes place between management and shareholders. Earning management is the only tool used by management for balancing their level of earning for various areas of the companies. This study is providing information about whether earning management has impact on dividend policy. Serita \& Hanaeda (2007) studied emerging market in which they concluded that there is positive tendency for companies to make payment of dividend, but there are some companies which do not regulate dividends because of their financial needs. Healy (1999) is of the opinion that managers typically manage and manipulate profits of firm to enhance the level of their bonuses, it is an important managerial reward to management which is to be examined using accrual. Managers comprehend inside information of firm and then decide about earning and dividend. The literature shows that both dividends and the fir level of earnings are interconnected. Scholars have tested that dividends are vital for the signaling control nearby the upcoming earning of the firms (Kumar \& Lee, 2001) while earnings can also expect around the coming dividends declared by the company (Miller \& Rock, 1985). The description of dividend procedure is one of the major worries in economic management. It is important for financial executives to develop dividend policy of the corporation.

Various studies have been carried out in respect of dividend policy, the aspects touching the dividend policy and consequences of dividend policy are still essential to be discovered. By the violation of accounting standards, it is very hard to find earning management which is done by the auditors. The prediction of the EM is purely made on the use of discretionary accruals. The model of Jones (1995) is used to measure discretionary accruals. Earnings management is a technique used by a company to level their earnings. This study is an attempt to examine that whether earning-management has any impact on divi- policy and also to examine the moderating role of audit quality on the relationship between earn-mgt and divi- policy. The literature recommends that dividends as well as the firm earnings are interconnected. Scholars have recognized that dividends have a signaling control about the upcoming earnings of the firm (Kumar \& Lee, 2001) and it has also been found that earnings can also be forecasted around the upcoming dividends declared by the business and hence has a key importance for both the firm and investor (Miller \& Rock, 1985; Fama \& Babiak, 1968). In this respect objectives of the study are to asses the effect of earnings management on dividend policy and also to examine the moderating effect of audit quality in knowing its role for the test of moderator in EM and Div- policy. 


\section{Literature Review}

\subsection{Dividend Policy}

Many studies have been conducted to analyze corporate dividend behavior. Linter's study is perhaps one of the pioneering studies on corporate dividend policy. Linter's (1956) argued that dividend represent a very determining variable used in financial policymaking in most oftenly the investor and management consider the D-policy as vital and primary and then the retained earning meaning that D-policy is primary case for the management-. The investor always think about the current earning and the very recent past dividend in the firm eye. The study of Bhat and Pandey (1994) examined managerial observations of dividend decision for a pattern of four hundred and twenty-five Indian firms from 1986 to 19991. Results confirmed that the normal dividend ratio become fifty four percent for the samples of both revenue making and loss-making organizations and the normal dividends vary between $14.3 \%$ to $19.2 \%$.

\subsection{Earning Management}

Earnings management has been broadly used in various company affairs and crisis for explaining the effect on motivation of management to operate stated earnings. Healy and Wahlen (1999) contended that EM is vitally considered while supervisors use in their planning and other reporting and in shaping dealings to adjust economic reports both to misguide certain stakeholders or to persuade promised consequences that rely upon suggested accounting information. The incentive of earning management changed into labeled into three classes: capital market prospects and valuation, agreements which might be written in term of accounting information and a kind of the antitrust or other relvant government laws. Primarily based on these motivations, earning management has been the incentives to respond on the impact of company procedures consisting of preliminary public related specific offerings ( Teoh et al., 1998); seasoned sort of the equity type offerings (Rangan 1998); management buyouts (Wu,1997) and the kind of takeovers practiced (Christie and Zimmerman, 1994).

\subsection{Dividend Policy and Earning Management}

A strong corporate governance observes minimization of the likelihood of earnings management in a firm (Ambarish et al. 1987). However sometime earnings management was required to sustain the dividend pay-out ratio of a firm because it was considered a sign of upcoming growth opportunities of a company in market. According to Lie and $\mathrm{Li}$ (2005) the vitally important is the decision about the D-policy in term of volume and recurring magnitude was estimated in regard to all premium been imposed in line with by capital markets on their dividends. Savos and Webar (2006) excluded this supposition and demanded dividend rise as a reward for the inadequate return to owners. And, it was not compulsory for the supervisors to accomplish their stated earnings for signaling higher value of their company as dividend pay-out could be affected by several aspects as well. So, from the previous study it reveals direct relationship between EM and dividend pay-outs.

\subsection{Audit Quality and Earning Management}

Earnings management typically based on the accruals characterized by approximations in the economic reporting procedure. For instance, present earnings might be increased by undervaluing bad debts on account receivables or predictable guarantee charges on the 
products sold (Huang et al., 2008). The amount of earn-management might be contingent on the firm's auditor. The firm can implement a further conservative method to economic reporting in the appearance of an advanced excellence audit (Mc Nichols and Stubben, 2008). Therefore, further investigators take observed AQ is the vital factor of the firm quality of earning (Lenard and $\mathrm{Yu}, 2012$ ). Boone et al.,( 2010) also in respect to the importance of AQ predict it as the key to enhance the ability of the firm earning. Researchers who examined U.S. businesses used The application of various procedures of the Big-4 to predict their audit quality and properly analyzed these firms. The researchers also found that the excellence of audit is the usually the intent of the firm regarding it and the prevailing quality can make it different. EM is probable to decline in states which take effective lawful structure to keep participants' right other than AQ, as solid protection controls insiders' services to increase own benefits.

Various researchers and theorists proclaimed that there is somehow exist relationship between AQ and earn-mgt. Majoor and Vanstraelen (2002) studied the impact of the sort of determinants of AQ , national audit environment and dependence on international capital markets on earning management. The result indicated that earning management is effected by audit quality of audit firm. The study of Chen at al. (2005) investigated the relationship between earning management and audit quality for Taiwanese firms. Their study concluded that quality audit constrains earn-management and provides accurate information. Piot and Janin (2007) studied the impact of various sort of AQ dimensions on earn-mgt in France. The study concluded that the existence of audit committee minimizes earning management activities and the presence of big five audit firms do not impact earning management activities in a firm.

\subsection{Audit Quality and Dividend Policy}

Deshmukh (2003) commented on the relationship between audit quality and divi- policy that asymmetry of information increases between investors and firms as a result of substandard audit quality in financial reporting, this result in lower dividend payout ratios for firms. Deshmukh (2005) further contended that if a firm has the lowest number experts of finance would have in higher level of information asymmetry. Allen et al. (2000) argued and told about the key importance of the payment made by the firm in term of the dividend and called it a kind of signal for the high quality regarding audit in a firm. Firms with higher dividend payout ratio are signal of the quality they are maintaining in their financial reporting. Mitton (2004) in his study concluded that firms having highest standard of audit would give more attention to the volume and amount of dividend to the shareholders.

\subsection{Empirical Studies}

Various studies explored, portrayed and explained the influx between the firm EM and the D_policy, these include. Aini et al (2006) explain that the management of earning is done in companies where the managers are concerned to show the better financial image of the company performance through discretionary accruals. Unequal information between directors and outside information employers permit supervisors to practice their decision in making and writing accounting for their personal benefit. Healy et al (1999) investigated that earnings management is an action wherever directors practice their judgment towards misinform stockholders about the financial activities of the firm or to 
affect predetermined results. Keisuk Netta (2006) studied how investor's value can be expanded with the pace of the making div-policy to avoid takeovers. Sava Savov (2006) examination suggested to further probe the connection between earnings management and investment and the effect on dividend installments. Zulfiqar et. al. (2010) carried out study to discover that either dividend policy is very vital to influence the EM in both Pakistan and china. Their study concluded that discretionary accruals don't have any effect on the arrangement of dividend in these countries. Nitta (2006) conducted study on how shareholder's worth can be enhanced by bringing changes in dividend policy. The results show that dividend increase and repurchasing of shares boost share prices. Haider et al (2012) studied dividend policy is affected by earning-mgt in Pakistan. They investigate KSE 100 index listed firms for the year 2005 to 2009. The dividend specially the kind of payout ratio representing the D-policy is used as measures for D-policy and DA are used as substitutes for calculating earning management. Modified cross sectional model (1995) was used to measure DA. Results suggested that earn-mgt has significant influence on dividend policy.

Asif et al. (2011) studied the association representing the strength of the relation of Dpolicy and EM. The investigators have studied the data of 86 registered businesses for the period 2004 to 2009. They used common effect model for the data and the outcomes illustrates that there is no connection between divi-policy and EM. They also used dividend sort of payout ratio for the measurement of div-policy and Jones Model (1995) was used to the quantity and to quantify the earnings management and based results exhibited very relevant results and predicted that EM is vital for the D-policy. Moghri et al. (2013) investigates the outcome of earn-management on divi-policy of registered corporations in Iranian firms and cocluded that EM is the best predictor of the firm Dpolicy. This study was carried out from 2006 to 2011 using data of 140 firms. The result shows optimistic and significant association between earnin- mgt and div-policy. According to this study increase in discretionary accruals increases the level of dividend percentage. Abbasi et al. (2014) also assessed the type of various Iranian firms and proclaimed that E is a key to predict the D-policy and hence carry an impact. They used dividend payout ratio for measurement of div- policy, while the models of Jones (1991) is the vitally used approach in these sort of studies for the measurement of the EM, Dechow et al (1995) model too very vital used in such kind of studies, Kasznik (1999) and Kothari et al. (2005) were used for the measurement of earnings management. They find insignificant relationship between the practices of EM and dividend procedure. But the size of the business is negatively and significantly connected with dividend. They also concluded that small companies announce more dividends.

\subsection{Theoretical Framework}

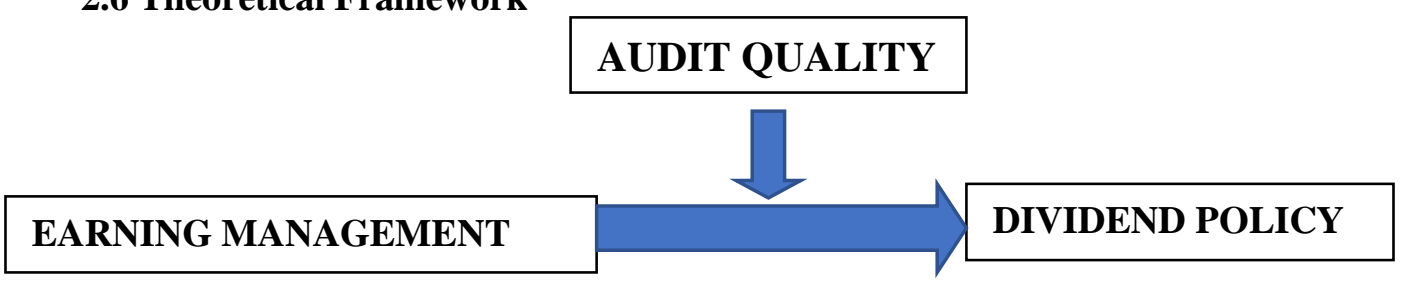




\subsection{Hypotheses}

The paper will test the following hypothesis.

H1: There is a relationship between earning management and dividend policy.

H2: Audit quality has influence on the relationship between earning management and dividend Policy.

\section{Research Methodology}

\subsection{Population and Sample}

The population of this study is all the firms listed in cement sector of Pakistan Stock Exchange (PSX). Cement sector having 20 firms listed in and are traded on the PSX. Firm which are delisted from the stock exchange during 2010 to 2016, are not included also firms with negative returns were also not included in the sample. As a result sixteen firms were left for this research study. Data have been collected from 2010 to 2016 from their published annual reports.

\subsection{Model Specification}

The following model is used to consider the effect of earning management and audit quality on dividend policy of the firms.
$D P O=\beta 0+\beta 1 D A+\mu t$
Where
DPO = Dividend payout ratio
DA $\quad=$ Discretionary accruals
$\mathrm{AQ} \quad=$ Audit quality
$\mathrm{DA}^{*} \mathrm{AQ}=$ Interaction term

$D P O=\beta 0+\beta 1 D A+\beta 4 A Q+\beta 5 D A * A Q+\mu t$

\subsection{Measurement of Variables}

\subsection{Earning Management}

Discretionary accruals widely used approaches to predict the firm EM. It is also used by various other studies of Healy (1985) \& Jones (1991). Discretionary accruals is mainly evaluated and calculated as bellow as:

\section{$T A=\Delta C A_{t}-\Delta C_{a s h}-\Delta C L_{t}+\Delta D C L_{t}-D E P_{t}$}

\subsection{Dividend Policy}

The D-policy is the vital main dependent variable, is calculated as:

\section{DPR= DPS/ EPS}

DPS $=$ Dividend per share

EPS = Earnings per share

\subsection{Audit quality}

Audit quality is used as moderating variable. Audit quality can be measured through auditor size, audit committee, and audit Fee. But in this study auditor size is used to measure audit quality.

\subsection{Auditor Size}

Auditor size is most comprehensive methodology of the AQ measurement. This is typically used in term of 4 big audit firms. It is coded as " 1 " if audit of firm is carried out by any of big 4 audit firms and is coded as ' 0 " if audit of the firm is not carried by any of these firms. 
4. Data Analysis

4.1 Descriptive Statistics

\begin{tabular}{|c|c|c|c|c|c|}
\hline & Min. & Max. & & Mean & S.D. \\
\hline DPO & -0.391 & 1.422 & & 0.281 & 0.297 \\
\hline DA & -0.461 & 0.451 & & 0.03 & 0.134 \\
\hline $\mathbf{A Q}$ & 0 & 1 & & 0.591 & 0.431 \\
\hline \multicolumn{6}{|c|}{ 4.2 Correlation Analysis } \\
\hline & DPO & & DA & & $A Q$ \\
\hline$\overline{\text { DPO }}$ & 1 & & & & \\
\hline DA & -0.113 & & 1 & & \\
\hline $\mathbf{A Q}$ & 0.091 & & 0.214 & & 1 \\
\hline
\end{tabular}

\subsection{Panel Data Diagnostic Statistics}

4.3.1 Heterescedasticity Test

Breush-Pagan/Cook Weisberg test is applied in order to test the panel level heteroscedasticity in the data. The null hypothesis is the existence of homoscedastic error variance. Result of test provided a chi-square value of 38.31 with the respective $p$-value of 0.071 . The result shows that chi-square statistic is insignificant at 5 percent level. Therefore the $\mathrm{H} 0$ is representing the constant variance was accepted. This also indicates that there exist no heteroscedasticity in the data.

\subsubsection{Serial Correlation Test}

The Wooldridge test is applied to check existence of autocorrelation in the data. The H0 represent about no autocorrelation. Test result provided F-statistic of 38.79 with corresponding p-value of 0.081 . It typically showed about the acceptance of the $\mathrm{H} 0$ and hence found no no autocorrelation.

4.3.3 Panel Model Regression Results

\begin{tabular}{lllllllll}
\hline \multicolumn{9}{c}{ Model 1 } \\
Variables & Coeff. & S.E & t-Stat. & P-Val & Coeff. & S.E & t-Stat. & P-Val \\
\hline DA & -0.079 & 0.031 & -2.54 & 0.002 & -0.0888 & 0.026 & -3.4 & 0.017 \\
AQ & & & & & 0.738 & 0.143 & 5.17 & 0.000 \\
DA*AQ & & & & & 0.0345 & 0.015 & 2.3 & 0.011 \\
R-Square & 0.213 & & & & 0.256 & & & \\
F-Statist. & 4.942 & & & & 6.241 & & & \\
\hline
\end{tabular}

DV= D.P.O

The above table shows regression results signifying the impact of EM on D-policy and moderating effect of audit quality on the impact of EM on D-policy. Model shows the impact of DA, the most in used proxy for the firm EM. Discretionary accruals have negative significant impact on dividend policy. This result was also confirmed by Shah et.al (2010), Im et.al.(2015) and Chansarn and Chansarn (2016). This result confirms that earning management is carried out to sustain a required level of dividends as dividend payout is considered an important signal for a prospective future growth. Firms may also involve in earning management to reduce their profits in order to pay less dividends if there are cash constraints with them. In case when earning management increases earnings capacity it leads to increase in stock prices, thereby a firm becomes more attractive to investors. Firms with high family ownership and institutional shareholding 
also involve in earning management as they demand smooth dividends and high yield on their stock returns. The result also shows that audit quality has significant positive impact on dividend policy. This is also confirmed by the studies of (Allen et al. 2000 \& Deshmukh, 2003). A lower audit quality increases asymmetry of information between investors and management which ultimately result in lower dividend payout ratios. High quality audit is a signal of quality in a firm which also results in higher dividend payouts to share holders. The interaction term DA*AQ in model two shows the moderating effect of audit quality on the relationship between earning management and dividend policy. R-Sqaure in model 1 was 0.213 and when DA*AQ the interaction term was included in model two the R-Sqaure has increased to 0.256. It shows that audit quality has moderating effect on the relationship between dividend policy and earning management.

\section{Conclusion}

This study is about assessing the impact of EM on the dividend related policy of the companies in cement sector of Pakistan. Also moderating effect of audit quality has been tested on the relationship between EM and D- policy. Data have been collected from the published annual reports taken from the sample firms been listed on Pakistan Stock Exchange (PSX) from 2010 to 2016. The result confirms that earning management has significant negative impact on dividend policy. This confirms that EM is carried out to sustain a required level of dividends as dividend payout is considered an important signal for a prospective future growth. Firms may also involve in earning management to reduce their profits in order to pay less dividends if there are cash constraints with them. The results of the study are having the nature of the previous studies and properly validate the obtained results of the past many researchers. Audit quality has significant positive impact on dividend policy which shows that quality audit improves quality in financial reporting and results in higher dividend payout ratios for shareholders. Audit quality is also used as a moderator on the relationship between EM and divid- policy. The result confirms that audit quality acts as a moderator between dividend policy and earning management.

\section{References}

Ambarish, R., John, K., \& Williams, J. (1987). Efficient signalling with dividends investments. The Journal of Finance, 42(2): 321-343.

Asif. A., Rasool. 1, W., \& Kama. Y. (2011). Impact of financial leverage on dividend policy. Empirical evidence from Karachi Stock Exchange-listed, "African Journal of Business Management", Vol. 5(4), 1312-1324.

Becker, C., DeFond, M., Jiambalvo, J., \& Subramanyam, K. (1998), The effect of audit quality on earnings management, Contemporary Accounting Research, 15, 1-24.

Chen, Y., Lin, K. L., \& Zhou, J. (2005). Audit quality and earnings management for Taiwan.Accounting and Business Research, Vol. 36, No. 1, pp. 33-52.

Christie, A. \& Zimmerman, J. (1994). Efficient and opportunistic choices of accounting procedures: Corporate control contests. The Accounting Review, 69(4): 539-566. 
Dechow, P., Sloan, R. \& Sweeney, A. (1995). Detecting earnings management. The Accounting Review, 70 (2): 193-225.

Deshmukh, S. (2005). The effect of asymmetric information on dividend policy . European Accounting Review, Volume 16, Issue, pp. 429 - 454.

Haider, J., Ali, A., and Sadiq, T. (2012). Earning management and dividend policy: Empiricalevidence from Pakistani listed companies. European Journal of Business and Management, 4(1), 83-90.

Haider. J, Ali. A \&Sadiq. T. (2012). Earning management and dividend policy: Empirical evidence from Pakistani listed companies, "European Journal of Business and Management”, Vol. 4 (12), 2222-1905.

Healy, P., \&Wahlen, M. (1999). A review of the earnings management literature and its implications for standard setting. Accounting Horizons, 13, 365-383.

Huang, A. H., Francis, J., Rajgopal, S., Zang, A.Y. (2008), CEO Reputation and Earnings Quality. Contemporary Accounting Research, 25(1), 109-147.

Jones J, (1991). Earnings management during import relief investigations. Journal of AccountingResearch, Vol. 29, pp. 193-228.

Kasznik, R. (1999). On association between voluntary disclosure and earnings management. Journal of Accounting Research, 37: 57-81.

Kothari, S., Leone, P., \& Wasley, C. (2005).Performance matched discretionary accrual measures. Journal of Accounting and Economics, 39: 163-197.

Kumar, P. \& Lee, B.S. (2001). Discrete dividend policy with permanent earnings. Financial Management, pp.55-76.

Lenard, M.J., Yu, B. (2012), Do Earnings Management and Audit Quality Influence Over Investment by Chinese Companies? International Journal of Economics and Finance, 4(2), 21-30.

Li, Y., Liu, J., \& Eddie, I. (2011). Share types and earnings management: Evidence from Chinese listed companies. Southern Cross University, Southern Cross Business School.

Linter, J. (1956). Distributions of incomes of corporations among dividends, retained earning and taxes. American accounting Review, 46, 97-113.

Maijoor, S. J. \& Vanstraelen, A. (2006). Earnings management within Europe: The effects of Markets Review, Vol. 5 No. 4, pp. 409-426.

McNichols, M.R., \& Stubben, S.R. (2008). Does earning management affect firms' investment decisions? The accounting Review, 83(6), 1571-1603.

Miller, M. \& Kevin. (1985). Dividend policy under asymmetric information. Journal of Finance, 40, 031-1051.

Miller, M. H. \& Rock, K. (1985). Dividend policy under asymmetric information. Journal of Finance, 40(4), 1031-1051.

Miller, M.H. \& Modigliani, F. (1961) Dividend Policy, Growth, and the Valuation of Shares. The Journal of Business, 34, 411-433.

Mitton, T. (2004). Corporate governance and dividend policy in emerging markets. Emerging Journal of Business and Economics. Vol. 44 No. 1, pp. 107-127. 
Moghri, A. E., \& Galogah, S. S. (2013). Effect of earnings management on dividend policy: Evidence from Tehran Stock Exchange. World of Sciences Journal, 1(2), 5865.

Piot, C. \& Janin, R. (2007). External auditors, audit committees and earnings management in IPO firms. Managerial Auditing Journal, Volume 20, pp. 86-104

Savov, S. (2006). Earnings management investment and dividend payments. Working paper university of Mannheim.

Shah, S. Z., Yuan, H., \& Zafar, N. (2010). Earnings management and dividend policy a empirical comparison between Pakistani listed companies and Chinese listed companies. International Research Journal of Finance and Economics, 35.

Teoh, S., Wong, T., \& Rao, G. (1998). Are accruals during initial public offerings opportunistic? Review of Accounting Studies, 3: 175-208.

Zulfiqar, Safdar \& Arshad (2009). Corporate governance and earning management and empirical evidence from Pakistan listed companies. European Journal of Scientific Research, Vol.26. No.4, pp 624-638. 